\title{
Protein content of rabbit embryos: one cell to peri-implantation blastocyst
}

\author{
P. M. Morgan and M. T. Kane \\ Department of Physiology, University College Galway, Galway, Ireland
}

\begin{abstract}
The protein content of rabbit embryos during the first 7 days of development in vivo was determined. The protein content of intact embryos, embryonic cells (intact embryos without mucin coats for developmental stages up to $96 \mathrm{~h}$ post-coitum and free of blastocyst coverings for later stages) and blastocyst coverings were determined by the Pierce Micro BCA assay. The mean protein content of intact one-cell or two-cell embryos was $0.16 \mu \mathrm{g}$ and increased at the four- to six-cell stage with no further increase until the late morula/early blastocyst stages (days 3 to 4 ). There was a 53 -fold increase in protein from the early to late blastocyst stages. The protein content of embryonic cells was stable at a mean value of $0.16 \mu \mathrm{g}$ until the late morula stage (day 3) and then increased to a mean of $6.85 \mu \mathrm{g}$ on day 6 and $50.38 \mu \mathrm{g}$ on day 7 . The increase in protein content of intact embryos up to about $72 \mathrm{~h}$ appeared to be due solely to an increase in the protein content of the mucin coat. The protein content of the blastocyst coverings increased from a mean of $2 \mu \mathrm{g}$ on day 5 to a mean of $35 \mu \mathrm{g}$ on day 7 . For blastocyst stages, the total protein content of intact blastocysts and of embryonic cells was correlated with the surface area of the embryos $\left(r^{2}=0.895\right.$ and 0.873 , respectively) and, thus, an increase in blastocyst size is a true index of blastocyst development.
\end{abstract}

\section{Introduction}

The preimplantation stages of rabbit embryonic development have been characterized by age post-coitum (Gregory, 1930), diameter (Alliston and Pardee, 1973) number of cells (Daniel, 1964) and DNA content (Lawitts et al., 1991). The intrazonal diameter of rabbit preimplantation embryos remains constant (approximately $125 \mu \mathrm{m}$ ) up to the third day of development (Daniel, 1964; Alliston and Pardee, 1973; Jung and Fischer, 1988); after this time, the diameter increases rapidly owing to blastocyst formation and expansion. The number of cells present has been determined directly for embryos up to day 5 post-coitum, and estimates made for later stages by calculating the number of cells needed to compose the surface (Daniel, 1964). At 7 days post-coitum, at about the time of implantation (Böving, 1959; Larsen, 1961), embryos have been estimated to contain approximately 255000 cells (Daniel, 1964) and have reached a diameter of $6 \mathrm{~mm}$ (Alliston and Pardee, 1973). In another study, an estimate of number of cells at day 6.5 postcoitum (219000), based on DNA, was obtained (Lawitts et al., 1991). Blastocysts at 7 days post-coitum were reported to have a protein content, evaluated from total nitrogen, of $500 \mu \mathrm{g}$ (Lutwak-Mann, 1971). Rabbit blastocysts at days 5 and 6 postcoitum were reported to have a protein content of 1.31 and $6.23 \mu \mathrm{g}$, respectively, as determined by the Lowry protein assay (Brinster, 1971). In another study, the average weight of blastocysts at days 6 and 7 post-coitum was reported to be 15 and $66 \mathrm{mg}$, respectively (Hafez and Sugawara, 1968). To our knowledge, no systematic study of the protein content of rabbit

Received 7 January 1992. embryos throughout preimplantation development has been performed. However, absolute amounts of protein through successive stages of development have been determined for embryos of mouse (Brinster, 1967; Schiffner and Spielmann, 1976), rat (Schiffner and Spielmann, 1976) and pig (Wright et al., 1981, 1983).

The extracellular coverings of the rabbit blastocyst are structurally more complex than the zona pellucida which surrounds all mammalian eggs. During the first 3 days postcoitum, rabbit embryos acquire a mucoprotein layer (mucin coat) on the outside of the zona pellucida, which is derived from tubal secretions (Böving, 1957; Denker and Gerdes, 1979). Starting at the early blastocyst stage (from $84 \mathrm{~h}$ post-coitum), erosion of the zona pellucida occurs and the zona is completely eroded at $108 \mathrm{~h}$ post-coitum (Denker and Gerdes, 1979; Fischer et al., 1991). Erosion of the zona pellucida appears to require uterine components (Fischer et al., 1991). From the fourth day post-coitum, a new layer, called the neozona, is deposited and this increases in size until implantation (Denker and Gerdes, 1979); the trophoblast may be involved in the deposition of the neozona (Leiser and Denker, 1988). An additional layer, the gloiolemma, which is derived from uterine secretions, is deposited on the outer surface of the mucin layer after day 6 post-coitum (Böving, 1957; Denker and Gerdes, 1979). In this study, the general term 'blastocyst coverings' will be used to describe the extracellular layers surrounding the blastocyst from day 5 to day 7. The term 'embryonic cells' is used to describe embryos up to the early blastocyst stage (day 4) which are surrounded by the zona pellucida, but have the mucin coat removed. 'Embryonic cells' when applied to later developmental stages includes the trophoblast and inner mass cells, but excludes all the blastocyst coverings. The protein content of 
intact embryos and of embryonic cells from individual embryos during the first 7 days of development was determined in this study.

\section{Materials and Methods}

\section{Embryos}

Fifty-two New Zealand White does were superovulated by treatment with follicle-stimulating hormone (Schering Co., Kenilworth, NJ; s.c. injections twice a day for 3 days, 0.3$0.5 \mathrm{mg}$ per injection, depending on the weight of the rabbit) followed 1 day later by simultaneous injection of 120 iu human chorionic gonadotrophin (CG, Chorulon: Intervet Ireland, Ltd, Dublin) and artificial insemination. Embryonic age is defined by referring to the time of hCG injection as time 0 , although ovulation does not occur until $10 \pm 2 \mathrm{~h}$ from this time (LutwakMann, 1971). Embryos $(n=701)$ at the specified stages of development were obtained at the following times after injection of hCG: one-cell at $18-23 \mathrm{~h}$, two-cell at $21-24 \mathrm{~h}$, four-six cell at $27-31 \mathrm{~h}$, early morulae at $42-48 \mathrm{~h}$, late morulae at $70-72 \mathrm{~h}$, early blastocysts at $92-96 \mathrm{~h}$, mid-blastocysts at $117-125 \mathrm{~h}$, late blastocysts at $142-144 \mathrm{~h}$ and post-implantation blastocysts at $166-170 \mathrm{~h}$.

The composition of the flushing medium was $0.1 \%$ polyvinylalcohol, $126 \mathrm{mmol} \mathrm{NaCl} \mathrm{l}^{-1}, 4.78 \mathrm{mmol} \mathrm{KCl} \mathrm{l}{ }^{-1}, 1.71 \mathrm{mmol}$ $\mathrm{CaCl}_{2} \cdot 2 \mathrm{H}_{2} \mathrm{O}^{-1}, 1.19 \mathrm{mmol} \mathrm{KH}_{2} \mathrm{PO}_{4} 1^{-1}, 1.19 \mathrm{mmol}$ $\mathrm{MgSO}_{4} \cdot 7 \mathrm{H}_{2} \mathrm{O}^{-1}, 10 \mathrm{mmol}$ Hepes $\mathrm{l}^{-1}$ and 500 iu penicillin $\mathrm{G} \mathrm{ml}^{-1}$ and $500 \mu \mathrm{g}$ streptomycin sulfate $\mathrm{ml}^{-1}$. This medium was neutralized to $\mathrm{pH} 7.4$ with $1 \mathrm{~mol} \mathrm{NaOH} \mathrm{l}{ }^{-1}$. Embryos were washed three times in flushing medium from which Hepes and the antibiotics were omitted, as these substances interfere in the protein assay. The intrazonal diameter of the embryos was measured using an eye-piece micrometer. The surface areas of blastocysts were determined, assuming that they were perfect spheres, using the formula $4 \pi r^{2}$, where $r$ is the intrazonal radius, in $\mathrm{mm}$.

One-cell and two-cell embryos were not surrounded by a mucin coat when they were recovered. Embryonic cells were obtained for later stages by the following methods. For developmental stages up to early blastocysts, the embryos were incubated in $0.25 \%$ pronase (Protease, Streptomyces griseus, Calbiochem, La Jolla, CA) at $37^{\circ} \mathrm{C}$ and monitored intermittently until the mucin coat was seen to be completely dissolved. The reaction was stopped by extensive washing of the embryos to dilute the enzyme. It was not possible to digest the zona pellucida of one-cell embryos in this study, as incubation with $1 \%$ pronase for $1 \mathrm{~h}$ at $37^{\circ} \mathrm{C}$ was ineffective. All developmental stages from that of mid-blastocysts (day 5) were dissected free of blastocyst coverings by placing them in a minimum volume of medium and bursting the blastocysts using a 26-gauge needle attached to a $1-\mathrm{ml}$ syringe; the embryonic cells were then easily dissected free. The embryonic cell masses were washed twice to remove any blastocoelic fluid present. All intact embryos, embryonic cells and blastocyst coverings were transferred, in a minimum volume of medium, into glass testtubes and checked using a dissecting microscope to ensure that all the embryonic material was at the bottom of the tube. (Up to 12 cleavage-stage embryos were pooled to ensure that enough protein was present to give accurate readings.) Samples of the third (final) washing solution served as blanks in the protein assay for each protein determination. Embryonic material and blanks were stored frozen at $-20^{\circ} \mathrm{C}$ until assayed. The samples were hydrolysed as previously described (Schiffner and Spielmann, 1976). While being viewed under the microscope, $5 \mu \mathrm{l}$ of $10 \mathrm{~mol} \mathrm{NaOH} \mathrm{^{-1 }}$ was added directly onto the embryonic material and the tubes were heated for $30 \mathrm{~min}$ at $56^{\circ} \mathrm{C}$. The solution was neutralized by the addition of $10 \mu \mathrm{l}$ of $5 \mathrm{~mol} \mathrm{HCl}{ }^{-1}$. Complete hydrolysis was confirmed by microscopic observation. The hydrolysed embryonic material was diluted to a final volume of $500 \mu \mathrm{l}$ and the total volume or aliquots of $50-200 \mu \mathrm{l}$ (for blastocyst stages) was assayed for protein.

\section{Protein determination}

The Pierce Micro BCA assay kit (Pierce, Rockford, IL) was used for protein determinations using the protocol supplied, except that the assay volume was halved. Protein standards containing $0,0.5,1.25,2.5,3.75,5,7.5$ and $10 \mu \mathrm{g}$ bovine serum albumin per $0.5 \mathrm{ml} \mathrm{H}_{2} \mathrm{O}$ were prepared. The standards were hydrolysed in the same manner as the embryonic material. The data for the standard curve were fitted to a straight line and the unknown protein was determined. A linear relationship was observed between protein concentration and absorbance for the range of standards used. The absorbance for the blank (final wash) was subtracted from the reading for each embryo. The within- and between-assay coefficients of variation were 4.5 and $4.9 \%$, respectively, at $4.5 \mu \mathrm{g}$ in $0.5 \mathrm{ml}$.

\section{Statistical analyses}

The protein contents of intact embryos and embryonic cells at successive periods up to and including the early blastocyst stage (day 4) were analysed by analysis of variance, and mean protein contents were compared using Tukey's $w$ procedure (Steel and Torrie, 1980). Later stages were not compared statistically because they were clearly different and because the variances were not homogeneous. However, the linear regression of protein contents on blastocyst diameter, surface area and volume was estimated for blastocyst stages.

\section{Results}

Intact embryos at the one- and two-cell stages of development had the same protein content, which was significantly lower than embryos at the four- to six-cell stage $(P<0.05)$ (Table 1 ). Between 27 and $46 \mathrm{~h}$ post-coitum there was no further increase in protein content. Between the early and late morula stages, an increase was again observed, with no further increase until the mid-blastocyst stage (Table 1). There was a 53 -fold increase in protein from the late morula/early blastocyst stage to the late blastocyst stages (Table 1). Blastocysts recovered at the same time were not a uniform size and this was observed especially at later stages of development (Fig. 1). There was even some overlap in the diameter of blastocysts recovered at successive $24-\mathrm{h}$ intervals (Fig. 1). The relationship between protein content 
Table 1. Protein content of intact rabbit embryos at successive stages of development

\begin{tabular}{lccl}
$\begin{array}{l}\text { Hours } \\
\text { after } \\
\text { hCG }\end{array}$ & $\begin{array}{c}\text { Number of } \\
\text { embryos } \\
\text { rabbits }\end{array}$ & $\begin{array}{c}\text { Protein }(\mu \mathrm{g}) \\
\bar{x} \pm \text { SEM }\end{array}$ & $\begin{array}{c}\text { Developmental } \\
\text { stage }\end{array}$ \\
\hline $18-23$ & $66 / 4$ & $0.16 \pm 0.01$ & 1 cell \\
$22-24$ & $43 / 3$ & $0.17 \pm 0.02$ & 2 cells \\
$27-31$ & $33 / 4$ & $0.28 \pm 0.07$ & $4-6$ cells \\
$45-46$ & $44 / 5$ & $0.29 \pm 0.04$ & Early morulae \\
$70-72$ & $26 / 4$ & $0.45 \pm 0.07$ & Late morulae \\
$92-96$ & $29 / 4$ & $0.47 \pm 0.05$ & Early blastocysts \\
$117-125$ & $47 / 8$ & $2.95 \pm 0.26$ & Mid-blastocysts \\
$142-144$ & $26 / 5$ & $25.03 \pm 3.04$ & Late blastocysts \\
\hline
\end{tabular}

hCG: human chorionic gonadotrophin.

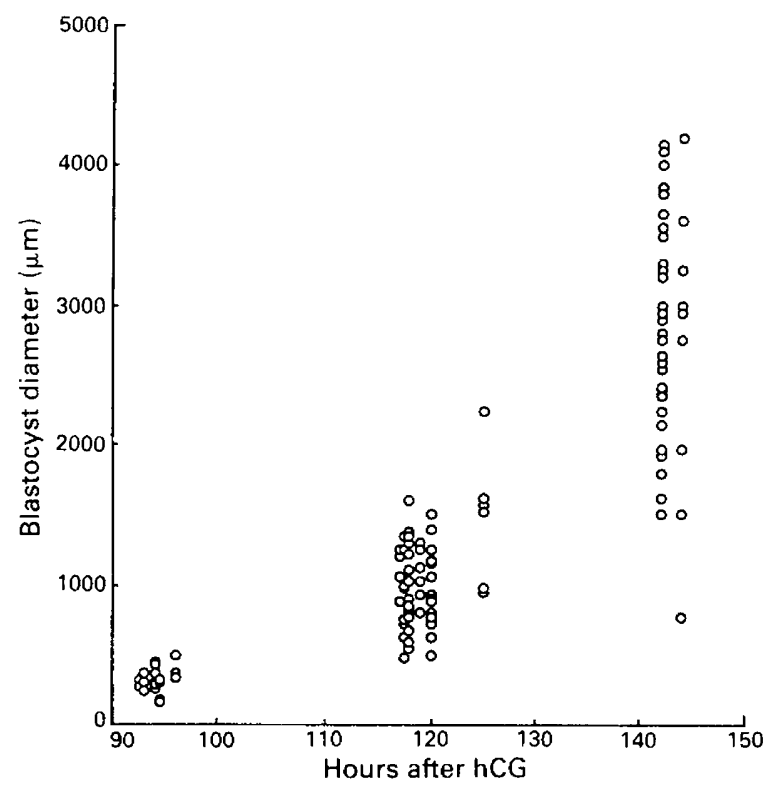

Fig. 1. Diameter of rabbit blastocysts as a function of time after injection with human chorionic gonadotrophin (hCG). Each point $(\mathrm{O})$ represents one blastocyst.

and blastocyst diameter, surface area or volume was therefore examined and the best fit of the data was obtained when protein content was expressed as a function of surface area. A linear relationship was observed between protein content of intact embryos and surface area (Fig. 2). The coefficient of determination between the protein content of intact blastocysts and surface area was 0.895 , indicating that only $10.5 \%$ of the observed variation was due to sources other than blastocyst surface area (Fig. 2).

The first significant increase in the protein content of embryonic cells occurred at the late morula stage $(P<0.05)$ (Table 2). Between days 4 and 6 , and 4 and 7 of development, the protein content increased approximately 15 -fold and 115fold, respectively (Table 2). There was a linear relationship between the protein content of embryonic cells of individual

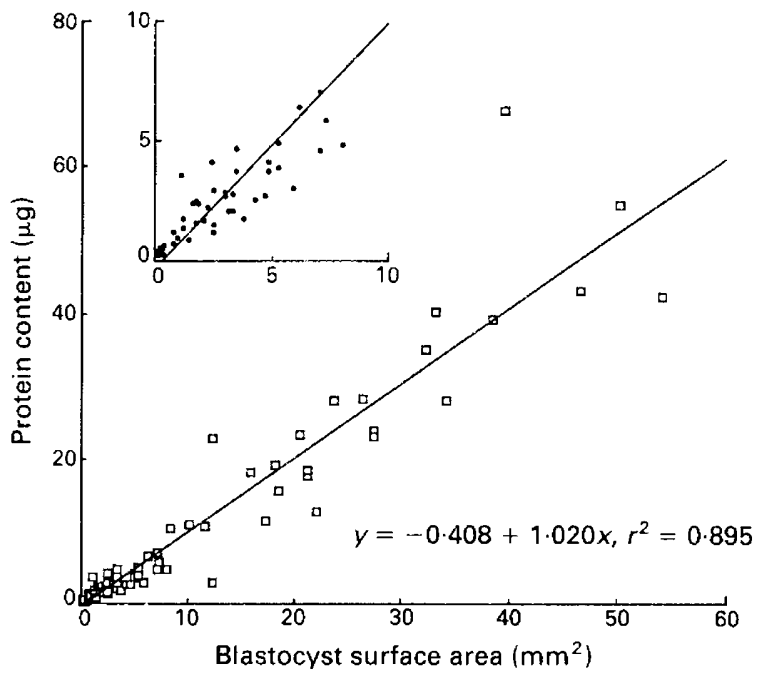

Fig. 2. Protein content of intact rabbit blastocysts expressed as a function of blastocyst surface area. For calculations of the surface area, blastocysts are assumed to be spherical and the formula used was $4 \pi r^{2}$, where $r$ is the intrazonal radius of the blastocysts in $\mathrm{mm}$. The total number of rabbits, protein determinations and blastocysts assayed were 17, 71 and 102, respectively.

Table 2. Protein content of rabbit embryonic cells from individual embryos at successive stages of development

\begin{tabular}{|c|c|c|c|}
\hline $\begin{array}{l}\text { Hours } \\
\text { after } \\
\text { hCG }\end{array}$ & $\begin{array}{l}\text { Number of } \\
\text { embryos/ } \\
\text { rabbits }\end{array}$ & $\begin{array}{c}\text { Protein }(\mu \mathrm{g}) \\
\bar{x} \pm \mathrm{SEM}\end{array}$ & $\begin{array}{c}\text { Developmental } \\
\text { stage }\end{array}$ \\
\hline $18-23$ & $66 / 4$ & $0.16 \pm 0.01$ & 1 cell \\
\hline $27-31$ & $64 / 4$ & $0.16 \pm 0.01$ & $4-6$ cells \\
\hline $42-48$ & $59 / 4$ & $0.16 \pm 0.02$ & Early morulae \\
\hline $70-72$ & $45 / 5$ & $0.22 \pm 0.01$ & Late morulae \\
\hline $94-96$ & $33 / 4$ & $0.44 \pm 0.05$ & Early blastocysts \\
\hline $117-125$ & $49 / 7$ & $1.55 \pm 0.15$ & Mid-blastocysts \\
\hline $142-144$ & $21 / 4$ & $6.85 \pm 0.79$ & Late blastocysts \\
\hline $166-170$ & $29 / 4$ & $50.38 \pm 1.51$ & $\begin{array}{l}\text { Peri-implantation } \\
\text { blastocysts }\end{array}$ \\
\hline
\end{tabular}

hCG: human chorionic gonadotrophin.

One-cell embryos were not surrounded by a mucin coat and the zona pellucida was intact. The mucin coat was removed enzymatically from embryos from the 4-6-cell stage up to the early blastocyst stage, but the zona pellucida was intact. For later stages of development, intact rabbit embryos were dissected free of the blastocyst coverings and washed free of blastocoelic fluid.

embryos and the surface area of the embryo from which they were derived (Fig. 3). The coefficient of determination was 0.873 , indicating that only $12.7 \%$ of the observed variation was due to sources other than blastocyst surface area (Fig. 3).

It was not possible to determine directly the protein content of the mucin coat of the cleavage-stage embryos, but it was estimated from subtraction of the mean protein values for embryonic cells (given in Table 2) from those for intact embryos (given in Table 1; see Table 3). These estimates imply that the 


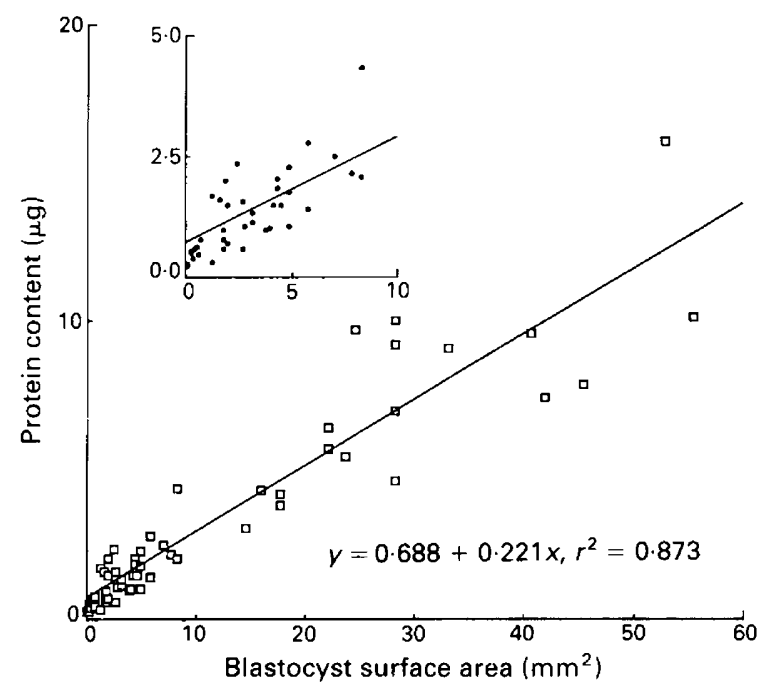

Fig. 3. Protein content of embryonic cells from individual rabbit embryos expressed as a function of the surface area of the blastocysts from which they were derived. Surface area was determined as given in Fig. 2. The total number of rabbits, protein determinations and blastocysts assayed were 15,58 and 103 , respectively.

protein content of the mucin layer remains relatively constant, at about $0.1 \mu \mathrm{g}$ for the four-six-cell stage and early morulae stages. An increase was observed at the late morula stage, followed by a dramatic decrease at the early blastocyst stage (Table 3). From the mid-blastocyst stage it was possible to dissect the blastocyst coverings free from the embryonic cells, and the protein content was determined directly (Table 3 ).

A linear relationship also existed between the protein content of the blastocyst coverings and the surface area of the intact blastocysts from which they were derived (Fig. 4) and the coefficient of determination was 0.752 . For the smaller blastocysts $\left(0-10 \mathrm{~mm}^{2}\right)$ this linear relationship appears slightly skewed (Fig. 4, insert).

\section{Discussion}

There is marked variation from one species to another in size of eggs, rate of cleavage, duration of the preimplantation period and duration of the gestational period. Implantation begins on day 7 post-coitum in rabbits (Böving, 1959), day 10 after oestrus in pigs (Hansel and McEntee, 1977) and between 96 and $108 \mathrm{~h}$ and between 120 and $132 \mathrm{~h}$ from the midpoint of the dark period, in mice and rats, respectively (Schiffner and Spielmann, 1976). The number of cells present in embryos at implantation varies from a mean of 86 in mice, 46 in rats (Schiffner and Spielmann, 1976) to about 255000 in rabbits (Daniel, 1964). These species differences should be considered when comparing data for protein content of preimplantation embryos.

The protein content of intact rabbit embryos at the one-cell stage is large $(0.16 \mu \mathrm{g})$ by comparison with other common laboratory species; the mean protein contents of one-cell rat and mouse embryos are 0.037 and $0.024 \mu \mathrm{g}$, respectively (Schiffner and Spielmann, 1976), but embryos of mice and rats are smaller. The mean protein content of a one-cell pig embryo is $0.273 \mu \mathrm{g}$
(Wright et al., 1981). There is a significant increase in protein at the late morula stage for intact rabbit embryos and embryonic cells. It is notable that the transformation from the morula to the blastocyst in rabbits is associated with a tenfold increase in the rate of protein synthesis per cell (Karp et al., 1974). This increase in the rate of protein synthesis at day 3 could be directly related to the observed rise in synthesis of new ribosomes at this stage (Schultz and Tucker, 1977).

One study has shown that between days 5 and 7 post-coitum the DNA content of rabbit embryos rises 100-fold (LutwakMann, 1971), but a more recent study has shown only a 25 -fold increase in DNA content during the same period (Lawitts et al., 1991). Between days 4 and 6, there is a 53-fold increase in the protein content of intact embryos and a 15-fold increase in protein content of embryonic cells. This dramatic increase in protein content during the preimplantation stage of development in rabbits is not paralleled in mice or rats (Schiffner and Spielmann, 1976). It is therefore not surprising that there is an absolute requirement for amino acids for the development of cleavage-stage rabbit embryos to blastocysts in vitro (Kane and Foote, 1970) and no such requirement for the culture of mouse embryos. A dramatic increase also occurs in the protein content of porcine embryos between days 6 and 9 of development, which is the time of blastocyst formation and hatching of the embryo from the zona pellucida (Wright et al., 1981).

In rabbits, the presence of the mucin coat on cleavage-stage embryos and blastocyst coverings adds a complexity not seen in other species. We estimate that the protein content of the mucin layer up to the early morula stage is about $0.1 \mu \mathrm{g}$. At this stage, the mucoprotein layer has been shown histochemically to have a low protein content (Denker and Gerdes, 1979). In this study the protein contents of intact embryos and embryonic cells and zona pellucida at day 4 post-coitum are similar, implying that little protein is present in the mucin coat. The neozona, which is formed after 4.5 days post-coitum, has been shown histochemically to be rich in protein (Denker and Gerdes, 1979) and, in the present study, blastocyst coverings at this stage had a high protein content. The neozona increases in thickness at 6 days post-coitum and histochemically is still rich in protein; the protein content of the mucoprotein layers also appears to increase (Denker and Gerdes, 1979). A dramatic increase in the protein content of blastocyst coverings at days 6 and 7 post-coitum was observed in this study.

Blastocysts from naturally ovulating does of identical gestational age have been shown to differ in their degree of development (Alliston and Pardee, 1973). The large variation in the diameter of blastocysts from naturally ovulating does (Alliston and Pardee, 1973) was also observed in this study for blastocysts from superovulated does, but the range of sizes overlap (results not shown). There is a linear relationship between the protein content of rabbit blastocysts and their surface area. This is not surprising when one considers that the rabbit blastocyst resembles a hollow sphere. Only $10.5 \%$ of the variance in protein content between individual blastocysts is due to factors other than embryonic surface area; this close relationship will permit the estimation of the protein content from a simple measurement of embryo diameter. For the intact blastocysts, there is a direct correspondence between surface area and protein, i.e. a doubling in surface area results in a doubling of protein content. It has been shown previously that 
Table 3. Protein content of rabbit embryonic coverings at successive stages of development as determined directly or as estimated from subtraction of the mean values for embryonic cells from those for intact embryos at matched times

\begin{tabular}{|c|c|c|c|c|}
\hline \multirow[b]{2}{*}{ Hours after hCG } & \multicolumn{2}{|c|}{ Determined directly } & \multirow{2}{*}{$\begin{array}{c}\text { Estimated } \\
\text { Protein }(\mu g) \\
\qquad \bar{x}\end{array}$} & \multirow[b]{2}{*}{$\begin{array}{l}\text { Developmental } \\
\text { stage }\end{array}$} \\
\hline & $\begin{array}{l}\text { Number of } \\
\text { embryos/rabbits }\end{array}$ & $\begin{array}{c}\text { Protein }(\mu \mathrm{g}) \\
\bar{x} \pm \mathrm{SEM}\end{array}$ & & \\
\hline $27-31$ & & & 0.12 & $4-6$ cells \\
\hline $42-48$ & & & 0.13 & Early morulae \\
\hline $70-72$ & & & 0.23 & Late morulae \\
\hline $92-96$ & & & 0.03 & Early blastocysts \\
\hline $117-125$ & $43 / 6$ & $2.30 \pm 0.29$ & 1.40 & Mid-blastocysts \\
\hline $142-144$ & $20 / 4$ & $18.01 \pm 1.97$ & 18.18 & Late blastocysts \\
\hline $166-170$ & $5 / 2$ & $35.02 \pm 3.96$ & & Peri-implantation blastocysts \\
\hline
\end{tabular}

hCG: human chorionic gonadotrophin.

Values for protein contents up to $96 \mathrm{~h}$ after hCG are indirect estimates of the mucin coat. The protein content of the directly measured blastocyst coverings include the mucin coat, neozona and, at later stages, the gloiolemma.

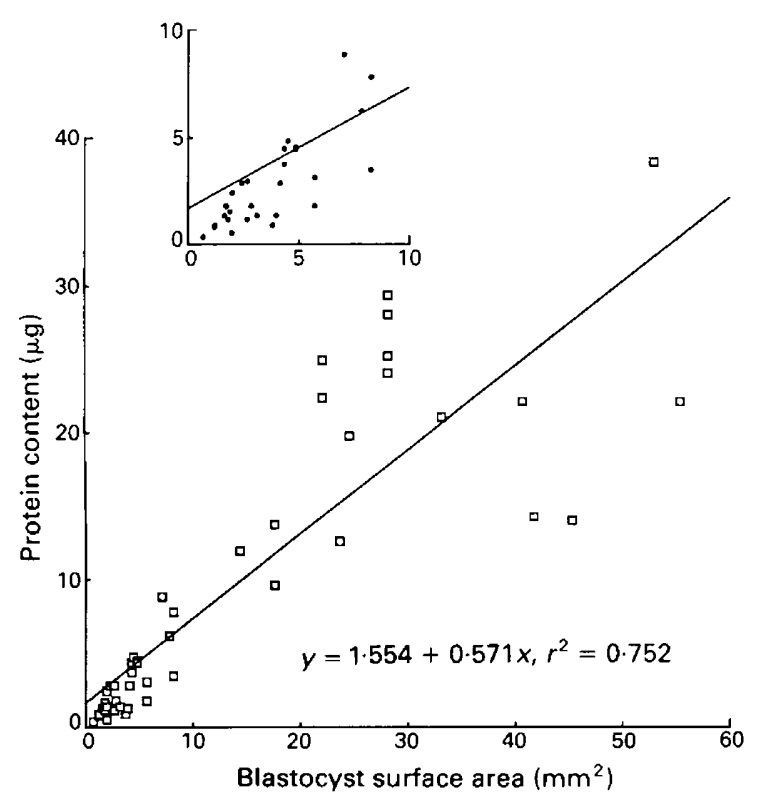

Fig. 4. Protein content of blastocyst coverings expressed as a function of the surface area of the blastocysts from which they were derived. Surface area was determined as given in Fig. 2. The total number of rabbits, protein determinations and blastocyst coverings assayed were 11,46 and 63 , respectively.

there is a close relationship between blastocyst diameter and metabolic activity in rabbit blastocysts grown in vivo (Jung and Fischer, 1988). Both DNA content and DNA polymerase activity have been shown to be linearly related to surface area of day 6 and 7 rabbit blastocysts (Lawitts et al., 1991). Blastocyst volume has been shown not to be correlated with blastocyst protein in pigs (Wright et al., 1983), although the length of the pig conceptus, between days 9 and 18, has been positively correlated with protein content (Anderson, 1978). The non-spherical elongated shape of the pig conceptus may account for these differences.

A knowledge of the protein content of rabbit embryos throughout the preimplantation period is important for interpretation of in vitro culture information and is also needed to study the metabolism of embryos through various stages of development. In this study, an increase in blastocyst diameter of embryos grown in vivo has been shown to be a true index of blastocyst development.

This work was supported by a Welicome Trust grant to M.T. Kane and P.M. Morgan.

\section{References}

Alliston CW and Pardee NR (1973) Variability of embryonic development in the rabbit at 19 to 168 hours after mating Laboratory Animal Science 23 665-670 Anderson LL (1978) Growth, protein content and distribution of early pig embryos Anatomical Record 190 143-148

Böving BG (1957) Rabbit egg coverings. Anatomical Record 127270

Böving BG (1959) Implantation Annals of the New York Academy of Sciences 75 700-725

Brinster RL (1967) Protein content of the mouse embryo during the first five days of development Journal of Reproduction and Fertility 13 413-420

Brinster RL (1971) Activity of 6-phosphogluconate dehydrogenase in the preimplantation mouse and rabbit embryo Experientia 27 371-372

Daniel JC Jr (1964) Early growth of rabbit trophoblast American Naturalist 98 85-97

Denker H-W and Gerdes H-J (1979) The dynamic structure of rabbit blastocyst coverings. I. Transformation during regular preimplantation development Anatomy and Embryology 157 15-34

Fischer B, Mootz U, Denker H-W, Lambertz M and Beier HM (1991) The dynamic structure of rabbit blastocyst coverings. III. Transformation of coverings under non-physiological developmental conditions Anatomy and Embryology 183 17-27

Gregory PW (1930) The early embryology of the rabbit Contributions to Embryology 21 141-168

Hafez ESE and Sugawara S (1968) Maternal effects on some biochemical characteristics of the blastocyst in the domestic rabbit Joumal of Morphology 124 133-142

Hansel W and McEntee K (1977) Female reproductive processes. In Dukes' Physiology of Domestic Animals, pp 772-800 Ed. MJ Swenson. Cornell University Press, Ithaca

Jung T and Fischer B (1988) Correlation between diameter and DNA or protein synthetic activity in rabbit blastocysts Biology of Reproduction 39 1111-1116

Kane MT and Foote RJ (1970) Culture of two- and four-cell rabbit embryos to the expanding blastocyst stage in synthetic media Proceedings of the Society for Experimental Biology and Medicine 133 921-925

Karp GC, Manes C and Hanh WE (1974) Ribosome production and protein synthesis in the preimplantation rabbit embryo Differentiation $265-73$ 
Lawitts JA, Butler JE, Kiessling AA and Biggers JD (1991) Growth and DNA replication in rabbit blastocysts Molecular Reproduction and Development 30 320-329

Larsen IF (1961) Electron microscopy of the implantation site in the rabbit American Joumal of Anatomy 109 319-334

Leiser $\mathrm{R}$ and Denker H-W (1988) The dynamic structure of rabbit blastocyst coverings. II. Ultrastructural evidence for a role of the trophoblast in neozona formation Anatomy and Embryology 179 129-134

Lutwak-Mann C (1971) The rabbit blastocyst and its environment: physiological and biochemical aspects. In The Biology of the Blastocyst pp 243-260 Ed. R) Blandau. University of Chicago Press, Chicago

Schiffner J and Spielmann H (1976) Fluorometric assay of the protein content of mouse and rat embryos during preimplantation development Journal of Reproduction and Fertility 47 145-147
Schultz GA and Tucker EB (1977) Protein synthesis and gene expression in preimplantation rabbit embryos. In Development in Mammals pp 69-87 Ed $\mathrm{MH}$ Johnson. Biomedical Press, Amsterdam

Steel RGD and Torrie JH (1980) Principles and Procedures of Statistics. A Biometrical Approach McGraw-Hill, New York

Wright RW Jr, Grammer J, Bondioli K, Kuzan F and Menino A Jr (1981) Protein content of porcine embryos during the first nine days of development Theriogenology 15 235-239

Wright RW Jr, Grammer J. Bondioli K, Kuzan F and Menino A Jr (1983) Protein content and volume of early porcine blastocysts Animal Reproduction Science 5 207-212 